\title{
Oral and systemic factors in xerostomia
}

\section{Relação de xerostomia com fatores bucais e sistêmicos}

\author{
Maria Sueli Marques SOARES ${ }^{1}$ iD https://orcid.org/0000-0003-0712-8456 \\ Raquel Lopes CAVALCANTI2 iD https://orcid.org/0000-0002-4615-9258 \\ Luiz Felipe Fernandes GONÇALVES ${ }^{3}$ ID https://orcid.org/0000-0001-6847-7524 \\ Ionária Oliveira de ASSIS ${ }^{3}$ iD https://orcid.org/0000-0002-4654-9088
}

\section{ABSTRACT}

Objective: The aim of this study was to evaluate the relationship among the following features: hyposalivation, systemic diseases and drug use, oral symptoms, dental condition, salivary flow and salivary $\mathrm{pH}$, as well. Methods: A cross-sectional study was performed with 50 participants diagnosed with xerostomia, randomly selected and distributed in two groups: 25 with hyposalivation and 25 without hyposalivation, paired in age and sex. Unstimulated Salivary Flow Rate (USFR), Decayed, Missing, Filled, Teeth (DMFT) index and salivary $\mathrm{pH}$ were determined. The Mann-Whitney test and chi-square test were applied, considering significant for $p$-values $<0.05$. Results: Among the participants with hyposalivation, $88 \%$ used drugs and 96\% presented systemic disease. And among those without hyposalivation, $48 \%$ used drugs and $64 \%$ presented systemic disease. The ones with hyposalivation showed the highest levels of dysgeusia (60\%) and burn mouth (36\%). There were statistically significant differences for the medians of USFR $(0.08 \mathrm{ml} / \mathrm{minute} / 0.2 \mathrm{ml} /$ minute) $(p=0.000), \mathrm{pH}(6 / 7)(p=0.000)$ and DMFT $(22 / 17)(p=0.004)$ obtained from participants with hyposalivation and without hyposalivation, respectively. Only in the group with hyposalivation there was a statistically significant association of unstimulated salivary flow rate with age $(p=0.035)$, type of systemic disease $(p=0.049)$ and $\mathrm{pH}(p=0.032)$ and DMFT demonstrated an association with systemic diseases $(p=0.015)$. Conclusion: The research results have suggested that hyposalivation worsens dental status triggering oral symptoms, and that salivary flow is influenced by the type of systemic disease and age group.

Indexing terms: Saliva. Oral health. Xerostomia.

\section{RESUMO}

Objetivos: Avaliar a relação entre hipossalivação, doenças sistêmicas e uso de medicamentos, sintomas bucais, experiência com cárie, fluxo e pH salivar. Métodos: Realizou-se estudo transversal com 50 participantes com xerostomia, selecionados e distribuídos aleatoriamente em dois grupos: 25 com hipossalivação e 25 sem hipossalivação, pareados em idade e sexo. Determinou-se o fluxo salivar em repouso (FSR), índice de dentes cariados, perdidos e obturados (CPO-D) e pH salivar. Aplicou-se teste de Mann-Whitney e teste qui-quadrado, considerando significantes valores de $p<0,05$. Resultados: No grupo de participantes com hipossalivação 88\% usavam medicamentos e 96\% tinham doença sistêmica e, entre os sem hipossalivação, 48\% usavam medicamentos e $64 \%$ tinham doenças sistêmicas. Aqueles com hipossalivação tiveram os maiores percentuais de disgeusia (60\%) e ardor bucal (36\%). Houve

\footnotetext{
$\nabla \nabla v$

1 Universidade Federal da Paraíba, Centro de Ciências da Saúde, Departamento de Clínica e Odontologia Social. Campus I, Cidade Universitária, 58051-900, João Pessoa, PB, Brasil. Correspondence to: MSM SOARES. E-mail: <msuelimarques@gmail.com>.

2 Faculdade Nova Esperança de Mossoró. Mossoró, RN, Brasil.

3 Universidade Federal da Paraíba, Programa de Pós-Graduação em Odontologia. João Pessoa, PB, Brasil.

$\boldsymbol{\nabla} \boldsymbol{\nabla} \boldsymbol{v}$

How to cite this article

Soares MSM, Cavalcanti RL, Gonçalves LFF, Assis IO. Relação de xerostomia com fatores bucais e sistêmicos. RGO, Rev Gaúch Odontol. 2021;69:e20210037. http://dx.doi.org/10.1590/1981-863720200003720200071
} 
diferenças estatisticamente significantes para as medianas de FSR $(0,08 \mathrm{ml} /$ minuto $/ 0,2 \mathrm{ml} / \mathrm{minuto})(p=0,000), \mathrm{pH}(6 / 7)(p=0,000)$ e CPO-D (22/17) ( $p=0,004)$ obtidas dos participantes com hipossalivação e sem hipossalivação, respectivamente. Apenas no grupo com hipossalivação houve associação estatisticamente significante do fluxo salivar em repouso com faixa etária ( $p=0,035)$, tipo de doença sistêmica $(p=0,049)$ e $\mathrm{pH}(p=0,032)$ e, o CPO-D teve associação com doenças sistêmicas $(p=0,015)$. Conclusão: Os resultados sugerem que a hipossalivação piora a condição dental, favorece a presença de sintomas bucais e, o fluxo salivar em repouso sofre influência de doenças sistêmicas e faixa etária.

Termos de indexação: Saliva. Saúde bucal. Xerostomia.

\section{INTRODUCTION}

Saliva plays an important role in homeostasis and oral health. The reduction in salivary flow is a risk factor for oral diseases, and may increase the predisposition to symptoms such as dry mouth, dysgeusia, burning mouth and dysphagia, as well as provoke intolerance to acidic foods and condiments, and negatively interfer with life quality [1-9]. Both xerostomia and hyposalivation etiology present several local and systemic risk factors [10] which are as following: the side effects of medications, systemic diseases and radiotherapy of the head and neck $[2,7,11]$, as well, aging, female patients and the number of teeth in the oral cavity [12-15] are also identified as possible causes of reduced levels of salivary production. Xerostomia does not always come with salivary flow reduction or hyposalivation $[15,16]$ and their risk factors are believed to have a multidimensional relationship that is not fully understood [16].Taking in consideration that these two oral conditions have been increasing in the population [7], do not present specific effective treatment $[17,18]$ and that their risk factors probably develop unknown interrelationships, the present study aimed to evaluate the relationship among the following issues: hyposalivation, presence of oral symptoms, dental condition, salivary flow and $\mathrm{pH}$, systemic diseases and medication use in individuals presenting xerostomia complaints.

\section{METHODS}

\section{Study design and sample}

A cross-sectional study was carried out with adult individuals, of both sexes who sought treatment for xerostomia in a public dental service. The sample consisted of 50 participants with xerostomia symptoms regardless of etiology, selected and randomly divided into two groups: 25 individuals with hyposalivation and 25 individuals without hyposalivation, paired in age and sex. Incluclison criteria for the hyposalivation group was resting salivary flow equal to or less than $0.1 \mathrm{ml} /$ minute and for the group without hyposalivation the inclusion criteria was a resting salivary flow rate equal to or greater than $0.2 \mathrm{ml} /$ minutes. Patients' anamnesis was performed and data regarding age, sex, systemic diseases, use of medications, oral symptoms such as burning mouth and dysgeusia were collected, as well as saliva collection. The salivary $\mathrm{pH}$ was determined and the experience with caries was recorded through the DMFT index. All procedures were performed by a dentist single examiner. The study protocol was approved by the Human Research Ethics Committee of the Health Sciences Center of Federal University of Paraiba (No. 0086/13). Written consent was obtained from all participants.

\section{Diagnosis of hyposalivation}

Salivary flow sialometry at rest (SFR) was performed in order to diagnose hyposalivation. The patient was asked to sit at a $90^{\circ}$ angle, with his head down, and to remain without swallowing, speaking or moving his tongue, for one minute. Then, it was requested that all accumulated saliva be expelled in a graduated test tube. The procedure was repeated five times at every one minute. For the final reading, the foam was disregarded and the total salivary volume obtained was divided by 5 (salivary collection time), obtaining the SFR in $\mathrm{ml} /$ minute. Hyposalivation was considered when the $S F R$ was $\leq 0.1 \mathrm{ml} /$ minute.

\section{DMFT index and salivary $\mathrm{pH}$}

Dental caries experience was evaluated by the DMFT index corresponding to the average of teeth, decayed, lost and filled, and the final result was obtained through clinical examination, with the aid of a probe, mirror and adequate lighting. In order to determine salivary $\mathrm{pH}$, a colorimetric method was used with the Dentobuff ${ }^{\circledR}$ Strip test, which, according to the manufacturer's guidelines, placed a drop of saliva on the surface of a sample strip pad and after five 
minutes, the $\mathrm{pH}$ reading was performed, considering the changing color of the strip and comparing it with a $\mathrm{pH}$ colorimetric scale provided by the manufacturer. The scale classifies saliva with the following $\mathrm{pH}$ ranges: 4.5 to 5.75 (very acidic), 6 to 6.5 (acidic), 6.75 to 7.25 (neutral) and 7.5 to 9 (very alkaline).

\section{Statistical analysis}

The data obtained were tabulated using the SPSS program (Statistical Package for Social Science, Chicago, ILL), version 14.0 for WINDOWS, with a descriptive analysis and a Komogorov-Smirnov normality test. To compare the differences between the groups, the Mann-Whitney test was applied with the variables SFR, pH and DMFT and, to assess association, the chi-square test was used, considering significant values of $p<0.05$.

\section{RESULTS}

The demographic and health-related characteristics of the participants are shown in table 1. It was observed a predominance of female participants and also that the majority of participants were under 60 years of age, in both groups. The highest percentage found among participants with hyposalivation and the most prevalente systemic diseases were: cardiovascular 36\% (9), psychological
$8 \%(2)$, oral cancer $8 \%(2)$ and gastrointestinal $8 \%(2)$. While in the group without hyposalivation the following were more prevalent: hypercholesterolemia 12\% (3), cardiovascular diseases $8 \%$ (2), gastrointestinal diseases $8 \%(2)$ and osteoporosis $8 \%$ (2). It has also been observed that among individuals with hyposalivation the majority had taken medication, mainly antihypertensive drugs $36 \%$ (9) and psychotropic drugs 8\% (2). In the group without hyposalivation, there was a lower percentage of medication use and the most consumed drugs were antihypertensive, anti-lipid, anti-ulcer and bisphosphonates with 8\% (2) each. Participants with hyposalivation demonstrated a higher frequency of oral burning and dysgeusia than those without hyposalivation. Table 2 demonstrates that the participants with hyposalivation showed the salivary flow median at lower rest when compared to the group without hyposalivation, a statistically significant difference $(p=0,000)$. As for salivary $\mathrm{pH}$, in the group with hyposalivation, the median value was 6, with $56 \%$ (14) of individuals $\mathrm{pH} 6$; $16 \%$ (4) at pH 5 and $28 \%$ (7) at pH 7. It is observed that $72 \%$ presented an acidic or very acidic $\mathrm{pH}$. While in the group without hyposalivation, the $\mathrm{pH}$ showed a median of $7,9 \%$ (24) with $\mathrm{pH} 7$ and only $4 \% \mathrm{pH} 6$, that is, only $4 \%$ of the participants presented acid $\mathrm{pH}$. The differences were statistically significant $(p=0.000)$. It is also observed that the median of the DMFT between participants with hyposalivation was higher than that of the group without hyposalivation, with a statistically significant difference

Table 1. Demographic and health-related characteristics of the study participants.

\begin{tabular}{|c|c|c|c|c|}
\hline \multirow{3}{*}{ Age (median) } & \multicolumn{2}{|c|}{ Group with hyposalivation $n=25$} & \multicolumn{2}{|c|}{ Group without hyposalivation $n=25$} \\
\hline & \multicolumn{2}{|c|}{$50(29-67)$} & \multicolumn{2}{|c|}{$47(25-64)$} \\
\hline & $\mathrm{n}$ & $\%$ & $\mathrm{n}$ & $\%$ \\
\hline 29-39 & 4 & 16 & 5 & 20 \\
\hline $40-49$ & 6 & 24 & 7 & 28 \\
\hline \multicolumn{5}{|l|}{ Sex } \\
\hline Male & 5 & 20 & 5 & 20 \\
\hline Female & 20 & 80 & 20 & 80 \\
\hline Systemic disease & 24 & 96 & 16 & 64 \\
\hline Dysgeusia & 15 & 60 & 4 & 16 \\
\hline
\end{tabular}


Table 2. Sample distribution of salivary flow at rest, DMFT and pH, differences between the groups studied.

\begin{tabular}{lcccc}
\hline Value & Group with hyposalivation & & Group without hyposalivation & $\mathrm{pH}$ value \\
\cline { 1 - 1 } Variable & Median (Minimum - Maximum) & Median (Minimum - Maximum) & $0.000^{*}$ \\
SFR & $0.08(0.00-0.10)$ & $0.20(0.12-0.80)$ & $0.004^{*}$ \\
DMFT & $22(12-28)$ & $17(6-26)$ & $0.000^{*}$ \\
\hline
\end{tabular}

Note: * Statistically significant. DMFT: Decayed, Missing, Filled, Teeth; SFR: Salivar Flow at Rest ml/minute; pH:

$(p=0.004)$. Only in the group with hyposalivation there was a statistically significant association between salivary flow at rest and the following variables: age group $(p=0.035)$, type of systemic disease $(p=0.049)$ and $\mathrm{pH}(p=0.032)$. Regarding the systemic disease variable a statistically significant association with DMFT $(p=0.015)$ was observed.

\section{DISCUSSION}

Comparing the results of the two groups studied, a higher frequency of systemic diseases and medication consumption can be evident among participants with hyposalivation. This finding reinforces the results of studies indicating that drugs and systemic diseases are important probable etiological factors for dysfunction of the salivary glands $[2,7,10,16]$. The types of medication most consumed by hyposalivation participants were antihypertensive and psychotropic drugs. In the literature these drugs are considered xerostomics $[2,16,19,20]$. An association of salivary flow at rest with systemic diseases was also observed $(p=0,015)$ in agreement with another study, in which the authors believe to be a complex and multidimensional relationship of the factors involved in the etiology of xerostomia and hyposalivation [16]. There is evidence that the medication use increases the risk for xerostomia and hyposalivation. Generally, drugs cause hyposalivation through the impact on central and peripheral receptors, resulting in anticholinergic activity against M3 muscarinic receptors [21]. Several authors claim that the prevalence of xerostomia and hyposalivation increases in individuals who consume polypharmaceuticals $[2,22]$ and, it is believed that the medication consumption is more predictive of the risk for hyposalivation than other factors such as age or sex [21].

Participants with hyposalivation showed higher percentages of oral burning and dysgeusia than those without hyposalivation, which corroborates other studies in which the presence of these symptoms was also reported more frequently among individuals with reduced salivary flow $[3,6,23]$. A possible justification for the findings of the present study would be that the reduction of the salivary flow and the qualitative alteration of the saliva can modify the response of receptors present in the taste buds of the oral mucosa of these individuals, imparing and/or altering the gustatory perception. Evidence has shown that the presence of systemic diseases and/or the medication use can cause oral symptoms such as burning mouth and dysgeusia. Nonetheless mouth burning is related to both conditions, while dysgeusia is more common with the use of certain drugs, such as psychotics [23]. In the present study, the frequency of dysgeusia was higher among individuals with hyposalivation (60\%) and the use of psychotropic drugs was reported only among individuals in this group. Saliva plays an essential role in detecting the taste of foods $[24,25]$, since it takes places in processes such as: solubilization of substances, chemical interaction between salivary components and taste substances, and diffusion and dilution of substances in saliva. Moreover, saliva has components which stimulate taste receptors, as well as it plays a role in protecting the oral mucosa and maintaining the receptors. Therefore it we can be assumed that regarding hyposalivation, salivary changes can influence the distorted perception of flavors and alter the sensitivity of the oral mucosa $[25,26]$, causing dysgeusia and/or oral burning. The hyposalivation group showed a statistically significant association between the salivary flow at rest and the age group. A similar result was observed in other studies $[7,12,15]$. The authors believe that this finding is due to the increased consumption of medication, especially with polypharmaceuticals, as the individual's age increases [27]. Xerostomic drugs can modify the relationship between saliva and dental caries, considering that they cause a reduction in salivary flow, leading to a greater accumulation of dental biofilm and a reduction in the buffering action, favoring the caries. In addition, patients with dry mouth sensation generally 
report consuming sweets and acidic foods in order to relieve their symptoms, which contributes to increasing the risk of dental demineralization. Because these two conditions occur simultaneously, there is an imbalance in the remineralization-demineralization process, consequently resulting in carious lesions [28]. Hyposalivation and reduced flow can increase the risk for caries [29]. An association between hyposalivation and the number of teeth in the mouth has also been demonstrated, suggesting that having less than 20 teeth in the oral cavity increases the risk of hyposalivation $[14,15]$. This data corroborates the result of the present study in which the dental condition of the participants (DMFT) with hyposalivation was worse than that of those without hyposalivation, with $p=0.004$. The resting salivary flow of participants with hyposalivation showed a statistically significant association with salivary $\mathrm{pH}$. This data is in agreement with the result of another study in which a relationship was observed between the frequency and severity of caries with salivary $\mathrm{pH}$ [30].

\section{CONCLUSION}

The research results have suggested that the presence of hyposalivation worsens the dental condition, favors the presence of oral symptoms as well that the salivary flow at rest is influenced by systemic diseases and age group. Further studies are suggested for multidimensional analysis of factors associated with xerostomia and hyposalivation. Subsequent studies are needed in order to assess the causal relationship between the factors that were associated here with hyposalivation.

\section{Acknowledgment}

The authors would like to thank the Conselho Nacional de Desenvolvimento Cientifico e Tecnológico (CNPq, National Council for Scientific and Technological Development) for their support in the form of a scientific initiation scholarship.

\section{Collaborators}

MSM SOARES contributed to the conception, design and preparation of the study, analysis and interpretation of data and preparation of the paper. RL Cavalcanti supported to the design of the project, data collection and preparation of the paper. LFF Gonçalves supported to data interpretation and preparation of the paper. IO Assis supported to data interpretation and preparation of the paper.

\section{REFERENCES}

1. Fleming $M$, Craigs $C L$, Bennett MI. Palliative care assessment of dry mouth: what matters most to patients with advanced disease? Support Care Cancer. 2020;28(3):1121-1129. https://dx.doi.org/10.1007/s00520-019-04908-9

2. Lee KA, Park JC, Park YK. Nutrient intakes and medication use in elderly individuals with and without dry mouths. Nutr Res Pract. 2020;14(2):143-151.

3. Kim S-Y, Byun J-S, Jung J-K, Choi J-K. Clinical characteristics and gustatory profiles in patients with subjective taste complaints. J Oral Med Pain. 2019;44(3):103-111.

4. Minagi HO, Ikai K, Araie T, Sakai M, Sakai T. Benefits of longterm pilocarpine due to increased muscarinic acetylcholine receptor 3 in salivary glands. Biochem Biophys Res Commun. 2018;503(2):1098-1102. https://dx.doi.org/10.1016/j. bbrc.2018.06.125

5. Iwasaki M, Yoshihara A, Ito K, Sato M, Minagawa K, Muramatsu K, et al. Hyposalivation and dietary nutrient intake among community-based older Japanese. Geriatr Gerontol Int. 2016;16(4):500-507.

6. Imura H, Shimada M, Yamazaki Y, Sugimoto K. Characteristic changes of saliva and taste in burning mouth syndrome patients. J Oral Pathol Med. 2016;45(3):231-236.

7. Anil S, Vellappally S, Hashem M, Preethanath RS, Patil S, Samaranayake LP. Xerostomia in geriatric patients: a burgeoning global concern. J Investig Clin Dent. 2016;7(1):5-12.

8. Chaudhury NMA, Shirlaw P, Pramanik R, Carpenter GH, Proctor GB. Changes in saliva rheological properties and mucin glycosylation in dry mouth. J Dent Res. 2015;94(12):1660-1667.

9. Benn AML, Broadbent JM, Thomson WM. Occurrence and impact of xerostomia among dentate adult New Zealanders: Findings from a national survey. Aust Dent J. 2015;60(3):362-7.

10. Millsop JW, Wang EA, Fazel N. Etiology, evaluation, and management of xerostomia. Clin Dermatol. 2017;35(5):468-476. http://dx.doi.org/10.1016/j.clindermatol.2017.06.010

11. Thomson WM. Dry mouth and older people. Aust Dent J. 2015;60(S1):54-63.

12. Åstrøm AN, Lie SA, Ekback G, Gülcan F, Ordell S. Selfreported dry mouth among ageing people: a longitudinal, cross-national study. Eur J Oral Sci. 2019;127(2):130-138.

13. Rech RS, Hugo FN, Tôrres LH do N, Hilgert JB. Factors associated with hyposalivation and xerostomia in older persons in South Brazil. Gerodontology. 2019;36(4):338-344.

14. Flink H, Bergdahl M, Tegelberg $\AA$, Rosenblad A, Lagerlöf F. Prevalence of hyposalivation in relation to general health, body mass index and remaining teeth in different age groups of adults. Community Dent Oral Epidemiol. 2008;36(6):523-531.

15. Islas-Granillo $H$, Borges-Yáñez A, Fernández-Barrera MÁ, Ávila-Burgos L, Patiño-Marín N, Márquez-Corona ML, et al. Relationship of hyposalivation and xerostomia in Mexican elderly with socioeconomic, sociodemographic and dental factors. Sci Rep. 2017;7(January 2016):40686. http://dx.doi. org/10.1038/srep40686 
16. Ohara $Y$, Hirano $H$, Yoshida $H$, Obuchi $S$, Ihara $K$, Fujiwara $Y$, et al. Prevalence and factors associated with xerostomia and hyposalivation among community-dwelling older people in Japan. Gerodontology. 2016;33(1):20-27.

17. Frydrych AM. Dry mouth: Xerostomia and salivary gland hypofunction. Aust Fam Physician. 2016;45(7):488-492.

18. Gil-Montoya JA, Silvestre FJ, Barrios R, Silvestre-Rangil J. Treatment of xerostomia and hyposalivation in the elderly: A systematic review. Med Oral Patol Oral y Cir Bucal. 2016;21(3):e355-66.

19. Barbe AG. Medication-Induced Xerostomia and Hyposalivation in the Elderly: Culprits, Complications, and Management. Drugs and Aging. 2018;35(10):877-885. https://dx.doi. org/10.1007/s40266-018-0588-5

20. Johanson CN, Österberg T, Lernfelt B, Ekström J, Birkhed D. Salivary secretion and drug treatment in four 70-year-old Swedish cohorts during a period of 30 years. Gerodontology. 2015;32(3):202-210.

21. Scully C. Drug effects on salivary glands: Dry mouth. Oral Dis. 2003;9(4):165-176.

22. Abdullah MJ. Prevalence of xerostomia in patients attending shorish dental speciality in sulaimani city. J Clin Exp Dent. 2015;7(1):e45-53.

23. Cho GS, Han MW, Lee B, Roh JL, Choi SH, Cho KJ, et al. Zinc deficiency may be a cause of burning mouth syndrome as zinc replacement therapy has therapeutic effects. J Oral Pathol Med. 2010;39(9):722-727.
24. Fábián TK, Beck A, Fejérdy P, Hermann P, Fábián G. Molecular mechanisms of taste recognition: Considerations about the role of saliva. Int J Mol Sci. 2015;16(3):5945-5974.

25. Pedersen AML, Sørensen CE, Proctor GB, Carpenter GH. Salivary functions in mastication, taste and textural perception, swallowing and initial digestion. Oral Dis. 2018;24:1399-1416.

26. Mese H, Matsuo R. Salivary secretion, taste and hyposalivation. J Oral Rehabil. 2007;34(10):711-723.

27. Villa A, Polimeni A, Strohmenger L, Cicciù D, Gherlone E, Abati S. Dental patients' self-reports of xerostomia and associated risk factors. J Am Dent Assoc [Internet]. 2011;142(7):81181-6. http://dx.doi.org/10.14219/jada.archive.2011.0269

28. Thomson WM, Lawrence HP, Broadbent JM, Poulton R. The impact of xerostomia on oral-health-related quality of life among younger adults. Health Qual Life Outcomes. 2006;4:1-7.

29. Shimazaki Y, Fu B, Yonemoto K, Akifusa S, Shibata Y, Takeshita $\mathrm{T}$, et al. Stimulated salivary flow rate and oral health status. J Oral Sci. 2017 31;59(1):55-62. http://dx.doi.org/10.2334/ josnusd. 16-0372

30. Velásquez N, Péres-Ybarra L, J. Urdaneta C, Pérez-Dominguéz M. Sialometry and Concentration of Phosphate and Calcium in Stimulated Whole Saliva and Gingival Crevicular Fluid and Its Association With Dental Caries in Schoolchildren. Biomédica. 2019;39:157-169. 